\title{
Regional Specifics of the Development of Media Brands of Online Media Offices (For Example, the Republic of Tatarstan)
}

\author{
Elena Sergeevna Doroschuk \\ Kazan Federal University, Kazan, RUSSIA \\ (D) 0000-0001-8380-9304 SC 57189732362 \\ leona31@yandex.ru
}

Tatiana Sergeevna Staroverova

Kazan Federal University, Kazan, RUSSIA

sc 57192161091

ARTICLE INFO

Received: 4 August 2019

Accepted: 3 October 2019

Published: 10 November 2019

DOI: https://doi.org/10.29333/ojcmt/6276

\section{ABSTRACT}

The phenomenon of mediatization has an impact on social processes and culture, creating a new mediated world in which relentless competition and digital technologies cause the transformation of media systems. A striking case in point is the processes of conquering and retaining market segments in network spaces, which gives rise to new forms of media activity. One of them is media branding in the online media offices. A systematic and integrated approach to the study of regional media allows analyzing the market effects of the development of media brands based on a clear definition of the mission and values of the brand, its relationship and inclusion in the media information policy, infographic design (slogan, legend, trademark, corporate color and logotype, branded fonts, style), as dictated by the multilingualism of the media space. As a result of the study, it has been noted that the media brand is being formed in the minds of the audience, the brand success hinges on the degree of closeness of the real audience to that image that is created in the process of developing the publication's information policy. A media brand promotes the formation of communities of people that are indicative of promoting media content. The functional features of a regional media brand include: positioning of regional content, language specifics (multilingualism and / or bilingualism), contiguity of an audience, periodic stability of audience dimension, audience communication (representation as a community in a network space). The functions of the media brand in the region are the following: increasing competitiveness; legal protection; providing an emotional bond with the audience; creative stimulation. Four levels of regional media brand formation have been identified through the research: basic (it is possessed by the majority of media $81.9 \%$; average (13.6\%); high $-2.5 \%$; integrated $-2 \%$. In order to successfully create a media brand and manage this process, the media introduces new functional areas of activity, which comprise: image-building, promotion, marketing research, reputation. The media in their website representations use the values of their own media brand that are worth of consumers' belief to manage readers' loyalty and build audience loyalty.

Keywords: media brand, online media office, regional media system, media market, media branding tools, media product, media brand effectiveness 


\section{INTRODUCTION}

The basis of ideas about modern society and its features is the phenomenon of mediatization which penetrates into all spheres of social relations and has an impact on social processes and culture. John B. Thompson whose contribution to the development of the theory of mediatization is noticeable and significant was one of the first to speak about it (Ambrozas, 1997; Thompson, 1990). Mediatization has a direct influence on the formation of a media person who is engaged in everyday media practices as a participant and creator of content. The media sphere in which the processes of transformation of culture occur is subjected to the influences leading to changes. All this permits to define modern society as mediatizated (Korkonosenko, 2014; McQueil, 2013). The new mediatizated world is a world of tough competition in which, according to Vartanova, driven by digital technologies, the processes of transformation of media systems as a whole are taking place with a special emphasis on the transformation of the very forms of media existence - online media and social networks - the spaces that generate virtual reality - appear and begin to play a leading role along with traditional media (Vartanova, 2015).

Under these conditions, the issues of adaptation and promotion of media in network spaces for the conquest and retention of market segments are relevant. These marketing issues are most effectively addressed through branding processes. The classic brand definition is widely represented in the economic marketing literature.

Kotler and Pfoertsch speak of brand as a term, sign, symbol, pattern or combination thereof, designed to identify goods or services of sellers and to differentiate them from goods or services of competitors (Kotler \& Pfoertsch, 2006). Duane Knapp defines brand as the total sum of all the impressions gained by customers and consumers, which, as a result, add up to a certain mental representation based on perceived functional and emotional benefits (Knapp, 2006, p. 15). Knapp shows that in terms of management, the brand of a company is its most valuable ownership (Knapp Duane, 1999, 2006, 2014). In Russian media practice, the concept of media brand that has become usual is widely used, although, as many researchers believe, this term has not received the proper substantive content in terms of science and can be interpreted as a number of synonyms: "reputation", "name", "well-known product", and sometimes simply "product" (Khatiashvili, 2014). One thing that the researchers of the economic foundations of media activities reach an agreement about is: a strong publication must be created and supported by brand building or branding - only then one can expect breakthrough in the new media world.

The development of online technologies prompts the media to apply new formats of interaction in market media segments. One of these formats is online outlets (Doroschuk \& Staroverova, 2017) allowing not only to transfer the solution of the main tasks of promoting media content to the virtual environment but also to make it less vulnerable from the point of view of consumer interests. Given the high competitiveness of the mass media environment, it is important to foresee and develop the capabilities of publications to hold an existing audience and attract new flows. One of the common methods that contributes to consolidation in the media market is the process of forming proper media brand, which is considered to be one of the most effective methods for isolating media from a large number of competitors. This is especially important for regional segments of the media market. Therefore, this article is supposed to analyze the development of brands in the regional media market of Russia using the example of online offices of the leading publications of the Republic of Tatarstan and assess the market effects of this development. 
METHODS

Based on a systematic and integrated approach, 35 leading online media offices registered in the Republic of Tatarstan have been investigated.

In order to describe and evaluate the market effects of the development of media brands in the Republic of Tatarstan the following criteria have been identified: a clear definition of the mission and values of the brand, its relationship and inclusion in the media information policy, infographic design (slogan, legend, trademark, brand color and logotype, company branded fonts, style), the multilingualism of the media space.

\section{RESULTS}

As the study show, the concept of "brand" has undergone despecialization and to some extent has lost its original terminological meaning. On this count we agree with G.A. Khatiashvili's statement that brand in a media system ceases to be just a marketing term but is surrounded by additional characteristics, which makes it a synonym for a media product (Khatiashvili, 2014). According to Prescott, against the background of increased interest in the promotion processes in media practice, a steady appeal to this terminology is associated with the awareness of the need to use the advantages of branding in the media practice (Bender, 1993). According to Walter McDowell, it is important to study media as brands in the context of the development of media systems (McDowell Walter, 2006, p. 229). According to Thomas John Prescott, branding processes are closely related to management processes and integrated into its structure (Thomas, 2009).

Russian theory defines media branding as the process of promoting a brand or a trademark by distributing content in the media system via the media (Asmus, 2009; Chaplygina, 2013; Chumikov et al., 2016). In this context, media brand appears to be wellknown mass media with a constant loyal audience, possessing a clear-cut program (information policy), flexible and meeting the challenges of our time, having original design and content, occupying high ranking positions (large circulation and high citation rate (Khatiashvili, 2014). The brand of media is formed in the minds of the audience and its success directly depends on the degree of proximity of the real audience to that image that is created in the process of developing the information policy of the publication. The media brand has the peculiarity of forming around itself communities of people who are indicative of promoting the content.

An analysis of the media brands and theoretical literature presented in the region's media space made it possible to identify the functional features of the media brand: positioning of regional content, language specifics (multilingualism and / or bilingualism), proximity of the audience, periodic stability of the audience's characteristics, audience communication (representation as a community in the network space). The following media brand features have been identified:

- competitive growth (the brand helps to stand out against competitors, expands the field of competition, avoiding the restrictions on price and content segment - such as, for example, the Tatmedia brand - the Republican Agency for Press and Mass Communications (http://tatmedia.tatarstan.ru/);

- legal protection (the brand allows for providing legal protection for the unique characteristics of the produced media products, and also accompanies the expansion of new media products into new markets / market segments, as a quality mark); 
- focus on audience (the brand is a means of providing an emotional bonding with the audience as the main consumer of the media product, the brand's task is to facilitate the selection of information; prune the cost of its search, reduce the risks that arise);

creative incentives (the brand helps focus and increase the creative potential of editorial staff, simplifies working with partners and access to the best journalistic and other personnel in the information space).

The study of the process of formation of a regional media brand allowed us to identify four main levels of its formation.

The first level (basic) is represented by the presence in the media of a basis for creating a media brand: a media product/s to satisfy the information and communication needs of the audience. The specialization and thematic focus of media content creates the distinctive features of a media brand in the information field (this level is indicative of all district municipal publications of the Republic of Tatarstan, for corporate media represented in this segment of the republican media market, etc.).

The second level (average) is associated with the processes of positioning a media brand in the media space, which, according to Jean-Jacques Lambin, is connected with the choice of brand advantages that put it in a favorable light, which allows it to take its own place in the market (Lambin et al., 2017, p. 80). A unique selling proposition - a media product, is prescribed in this case from the standpoint of its importance to the audience: a clear idea of the vision, mission and values of the media brand makes it possible to determine the contribution of the media brand to the development of society, its filling as a public good. Here is also observed the brand's prognostic function: its vision in the future, both from the market segment and from the emotional perception of the audience. So is the media brand of the Tatarstan magazine, presented in the online office from the standpoint of three decisions: reasonable, kind, eternal (http://protatarstan.ru/), value-oriented, similar in the principles life, shared by the media with its audience.

The third level (high) enables not only to create media products and position in the media space, but also to build audience loyalty, working closely with it. The media brand of this level is characterized by the presence of stable ideas about the target audience, based on such characteristics as geographical, socio-demographic, behavioral and psychological. A profile, assembled according to these characteristics, involves the identification of parameters relative to which the media brand differs from competitors. This is the media brand of the Evening Kazan publication (http://www.eveningkazan.ru/).

The fourth level (integrated) is based on the processes of identifying media brand. The media brand has the following characteristics: a media product is different from media products of other brands; easily identified by the audience; it is in demand and shared from the standpoint of values and sociocultural markers, it uses a wide range of tools: name, slogan, legend, signs and company colors, logo, company branded fonts, design, advertising and image campaigns, a variety of formats of feedback link with the audience. The integrated level of media brand development is possessed by the Tatar-Inform news agency that leads the top 20 of the most cited media in Tatarstan (www.tatar-inform.ru).

The analysis of the compliance with the degrees of brand development gave an option of forming the four main groups of online media offices of the Republic of Tatarstan:

- a group with a basic degree of media brand development comprises online offices that meet one criterion $-81.9 \%$ of the entire array; 
- a group with an average degree of media brand development (matching the two criteria) $-13.6 \%$ of the entire sample;

- online media offices with a high level of media brand elaboration with representation according to a set of criteria $-2.5 \%$ of all online offices studied;

- $\quad$ online media offices with an integrated level of media brand elaboration, with a complete package of media branding tools $-2 \%$ of the samples studied.

The study has revealed a trend: the creation and development of media brand entails the emergence of new functional features in the online media representation and in the media itself. The newly formed functions for the study period (2014-2019) incapsulate:

- image function that promotes the formation and development of the media image, which is based on a combination of elements such as trademark, brand colors, logotype, company branded fonts, media channel design, advertising and image campaigns, principles of an audience capture;

- promotion function - promotion of own goods and services, providing the opportunity for publication of promotional content for third-party organizations;

- marketing research function - conducting research aimed at identifying the needs of the audience and monitoring the market for information services on the whole;

- reputation function - the brand is associated with certain journalists who represent the editorial board and create content for the media, the reputation of journalists working in the media is created and maintained.

\section{DISCUSSION}

Considering the specifics of the product created by the media, it must be emphasized that the process of creating media brand or media branding also has a number of specific features. Firstly, this is the imposition of typological parameters of media on marketing, which is connected with the initial orientation of the media on audience interests. Secondly, it is the presence of the target audience and ideas about it at the time of the start of work on the publication. Therefore, a specific feature of media branding also stems from these features of the very media.

Not insignificant thing for the media brand development is to take into account the specifics of a media product, which is defined by Lobodenko and Shesterkina as the result of the functioning of the system of mass communications, generating virtual reality of information spaces, and aimed at meeting the information needs of mass audience (Lobodenko \& Shesterkina, 2015). If the media brand cannot exist without a media product, then the media product, in turn, cannot be realized without media content, which is defined by Lukina as any data - text, sound, visual images or a combination of multimedia data presented in analog or digital format on a variety of media such as paper, microfilm, magnetic or optical storage devices (Lukina, 2010). The main components of media content are designated by the researchers as journalistic materials, PR - content, advertising and entertainment and business information (Lobodenko \& Shesterkina, 2015).

\section{SUMMARY}

The study of the brand formation process at the level of regional online media offices in the Republic of Tatarstan provides the following conclusions:

1. Media brand in a media system ceases to be just a marketing term; this concept is surrounded by additional characteristics, which allows it to be defined both from the standpoint of reputation management and as a synonym for a media product. 
2. Media brand in terms of media can be defined as a well-known media outlet with a constant loyal audience, with a clear program (information policy), flexible and responsive to the challenges of our time, with original design and content, ranking high.

3. The main functional features of the media brand in the region are related to the regional processes of media brand development which include: positioning of regional content, language specifics (multilingualism and / or bilingualism), proximity of the audience, periodic stability of audience characteristics, audience communication (representing as a community in a network space).

4. Four main levels of media brand formation in the regional media space have been identified: basic (the presence in the media of a basis for creating a media brand: media product/s, it is indicative of all district municipal publications of the Republic of Tatarstan, corporate media); average that is associated with the processes of positioning a media brand in the media space; high that allows not only to create media products and position in the media space, but also to build audience loyalty, working closely with it; integrated that is based on media brand identification processes.

5. The division of all online media offices into four main groups in accordance with the identified degrees of media brand development allows to conclude that the processes of media branding in the republican media space are insufficiently developed, since a larger percentage of media has the first - basic - degree of media brand development (81.9\%), which is due to the neglect of the features of audience communication in the activities of online media offices, the lack of attention to such newly appeared functions as image-building, promotion, marketing research function and reputation function.

\section{CONCLUSION}

Thus, the analysis of the processes of formation and development of media brands in the regional media space made it possible to single out the specifics of these processes associated with the structural and functional features of both the space itself and the system of online media offices.

Against the background of such features of the online environment as a high speed of information dissemination, a low level of protection against plagiarism, a high degree of rewriting of text information, to be unique and maintain exclusive content for a long time is a very time-consuming task. Therefore, to manage the loyalty of the readers and to build the audience loyalty, the media in their online outlets use the values of their own media brand, which have earned the trust of consumers. This allows them to become separate from their competitors and to cut through the clutter.

\section{ACKNOWLEDGEMENT}

The work is performed according to the Russian Government Program of Competitive Growth of Kazan Federal University.

\section{REFERENCES}

Ambrozas, D. (1997). [Review of the book The Media and Modernity: A Social Theory of the Media, by J. B. Thompson (1995)]. Communication. Information Médias Théories, 18(1), 193-195.

Asmus, A. V. (2009). Media Brand: Typological Characteristics. Electronic Science Journal MediaScope [Electronic Resource]. 2. Retrieved from http://www.mediascope.ru/ 
Chaplygina, M. A. (2013). The Development of Media Branding and its Essence in the Formation of Media Companies. Economics and Modern Management: Theory and Practice: The Collection of Papers of the 31st International Science-Practice Conference Issue, 11(31). Novosibirsk: SibAK.

Chumikov, A. N., Bocharov, M. P., Samoilenko, S. A. (2016). Advertising and Public Relations. Professional Competencies.

Doroschuk, E. S., \& Staroverova, T. S. (2017). Blog in the structure of the Internetrepresentations media: communicative aspect (on the example Republic of Tatarstan). Turkish Online Journal of Design Art and Communication, 7, 979-984.

Khatiashvili, G. A. (2014). Evaluation Parameters of the Editorial Component of the Media Brand (by the way of the example, the Russian Reporter and Snob magazines). Herald of Moscow University. Series 10. Journalism, (4). Retrieved on 6.6.2019 from https://vestnik.journ.msu.ru/books/2014/4/parametry-otsenki-redaktsionnoy-sostavl yayushchey-mediabrenda-na-primere-zhurnalov-russkiy-reporter-/

Knapp Duane, E. (1999). The Brand Mindset. McGraw-Hill Education.

Knapp Duane, E. (2008). The Brand Promise. McGraw-Hill Education.

Knapp Duane, E. (2014). Global Destination BrandScience. BrandStrategy, Inc.

Knapp, D. (2006). Brand-Specific Thinking. Progress, 174, 15.

Korkonosenko S. G. (2014). Personality in the Media Policy: Freedom and Regulation. Media and Information Literacy in Russia: A Way to the Future. Collection of Materials of the All-Russian Scientific-Practical Conference "Media and Information Literacy in the Information Society" (Moscow, April 24-27, 2013). I. V. Zhilavskaya (Ed.). MCBS, 93-102;

Kotler, F., \& Pfoertsch, W. A. (2006). B2B Brand Management. Springer. https://doi.org/10.1362/146934707X205877

Lambin, J.-J., Chumpitas, R., \& Schuling, I. (2017). Market Oriented Management. Second Edition. St. Petersburg: Peter, 80.

Lobodenko, L. K., \& Shesterkina, L. P. (2015). Media Brand: the Experience of Modeling Regional Online Media. Scientific Opinion, (8-1), 145-150.

Lukina, M. M. (Ed.) (2010). Online Media: Theory and Practice. The Aspect Press.

McDowell Walter, S. (2006). Issues in Marketing and Branding. Handbook of Media and Economics. Mahwah, New Jersey: Lawrence Erlbaum Associates, Publishers.

McQueil, D. (2013). Journalism and Society: Textbook. MediaMir.

The Top 20 of the Most Cited Media of The Tatarstan. Retrieved from http://www.mlg.ru/ratings/media/regional/4797/

Thomas, J. P. (2009). Media Management Manual. A Handbook for television and radio parishioners in countries-in-transition. UNESCO. Printed by Macro Graphics Pvt. Ltd. Published by: Communication and Information Sector United Nations Educational Scientific \& Cultural Organization. 134 p.

Thompson J. B. (1990). Ideology and Modern Culture. Critical Social Theory in the Era of Mass Communication. Stanford University Press.

Vartanova, E. L. (2015). Television: Post-Network Model [Electronic Resource]. The Art of Cinema, (4). Retrieved on 06/01/2019 from http://kinoart.ru/archive/2015/04/ televidenie-postsetevaya-model
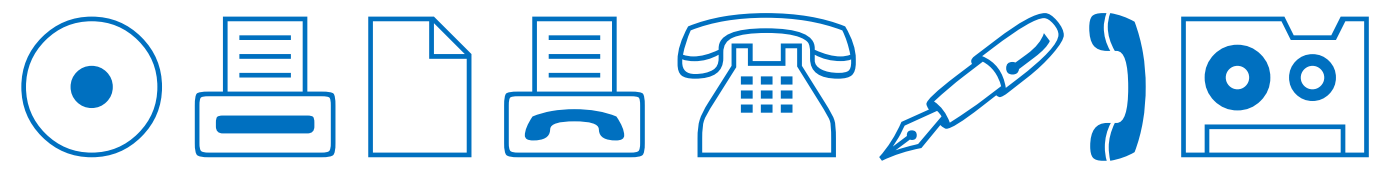